\title{
Н.А. Романько
}

\section{О НАУЧНО-МЕТОДИЧЕСКОМ ОБЕСПЕЧЕНИИ ЛАБОРАТОРНЫХ ИССЛЕДОВАНИЙ ПРИ ПРОИЗВОДСТВЕ СУДЕБНО-МЕДИЦИНСКИХ ЭКСПЕРТИЗ}

Бюро судебно-медицинской экспертизы, г. Москва

Резюме. В статье дана оценка состоянию нормативно-правовой базы РФ, регламентирующей порядок производства экспертиз трупов, живых лиц, материалов дела и биологических объектов. Автор приходит к выводу о необходимости адаптации нормативной и методической базы к новым методам исследования и к новым видам экспертиз с применением высокотехнологи- чного оборудования; разработки новых критериев, позволяющих регулировать производственную нагрузку и контролировать качество исследований.

Ключевые слова: судебно-медицинские экспертизы, новые технологии, нормативно-правовые акты.

В регламентирующем организацию и производство судебно-медицинских экспертиз приказе Минздравсоцразвития РФ от 12 мая 2010 года № 346н [2] предусмотрены штатные нормативы, определён порядок взятия и направления биологического материала на лабораторные и инструментальные исследования при различных видах экспертиз, предложен перечень оборудования для всех подразделений Бюро СМЭ. Однако его рекомендательный характер в свете продолжающегося реформирования приводит к ещё большей разобщённости в подходах к данным вопросам в регионах, имеющих различную методическую и материально-техническую базы.

Совершенствование аппаратно-технической базы и связанные с ним нововведения и разработки, выполняемые в порядке частной инициативы, влекут за собой возникновение определенных проблем, с которыми сталкиваются все бюро по мере совершенствования их материальнотехнической оснащённости.

Нередко можно услышать мнение о том, что компьютеризация исследований позволяет значительно повысить производительность труда эксперта.

И тут следует заметить, что использование компьютерных и высокотехнологичных аппаратных методов не только и не столько ускоряет процесс исследования и документального оформления результатов, сколько повышает качество экспертной работы и доказательность экспертизы в целом.

Одновременно эти методы требуют от эксперта не только специальных знаний в области судебной медицины и хорошего владения компьютерной техникой, но и большого кропотливого труда, нередко большего, нежели при традиционном «ручном» способе исследования.

Прогрессирующая тенденция роста количества экспертных заданий в лабораторных подразделениях ГБУЗ МО «Бюро СМЭ» значительно увеличивает экспертную нагрузку, что приводит к увеличению напряженности труда работников при «не лучших» условиях труда и это притом, что судебно-медицинская экспертиза должна

(C) Н.А. Романько, 2013 
отвечать требованиям оказания услуг высокого качества.

Одним из критериев качества выполнения экспертных заданий являются сроки исполнения экспертиз. Здесь большую роль играет приближённость лабораторных подразделений к танатологическим. К примеру, в ГБУЗ МО «Бюро СМЭ» действуют 46 районных судебномедицинских (танатологических) отделений. Помимо центральной судебно-химической и химико-токсикологической лаборатории функционирует межрайонный судебно-химический отдел, представленный 17 межрайонными судебнохимическими отделениями, расположенными в муниципальных образованиях Московской области. Судебно-гистологический отдел представлен 7 межрайонными отделениями и центральной гистологической лабораторией. Такая широкая сеть лабораторных подразделений вблизи районных танатологических отделений способствует резкому сокращению сроков производства экспертиз трупов.

Качество экспертиз также зависит от широкого применения экспертных методик и имеющихся в распоряжении ГБУЗ МО «Бюро СМЭ» технических средств, что способствует объективному, всестороннему и научно-обоснованному решению поставленных перед экспертом вопросов. Следует заметить, что до настоящего времени методологические основы производства судебно-медицинских экспертиз вещественных доказательств разработаны не в том объёме, который соответствовал бы современному уровню развития медицинской науки и техники.

В соответствии с Приказом Минздравсоцразвития от 12 мая 2010 года №346 н [2] при производстве судебно-медицинских экспертиз используются медицинские технологии, разрешенные к применению на территории Российской Федерации, а также другие рекомендованные методики.

При производстве судебно-медицинских экспертиз в структурных лабораторных подразделениях ГБУЗ МО «Бюро СМЭ» должны использоваться медицинские технологии, разрешённые к применению Федеральной службой по надзору в сфере здравоохранения и социального развития в установленном порядке.

С целью унификации экспертных исследований и создания единого научно-методического подхода к экспертной практике в ГБУЗ МО «Бюро СМЭ» была проведена большая работа по реализации приказов Минздравсоцразвития России от 31.12.2004 г. № 346 [3] и от 20.07.2007 г. № 488 [4].

Ведущими специалистами ГБУЗ МО «Бюро СМЭ» в течение 2010-2011 гг. разработаны, утверждены Федеральной службой по надзору в сфере здравоохранения и социального развития и внедрены в экспертную практику 32 новые медицинские технологии. На 01 января 2012 г. в Российской Федерации зарегистрирована 81 меди- цинская технология для производства судебномедицинских экспертиз [1].

В п. 4 статьи 10 Федерального закона от 21 ноября 2011 г. № 323-Ф3 «Об основах охраны здоровья граждан в Российской Федерации» [5], вступившего в силу с 1 января 2012 года, указано, что доступность и качество медицинской помощи обеспечиваются «применением порядков оказания медицинской помощи и стандартов медицинской помощи». На сегодняшний день в судебно-медицинской службе не существует каких-либо стандартов выполнения различных видов судебно-медицинских экспертных исследований. Существующие стандарты утверждены на местном уровне - в отдельных Бюро СМЭ, и нормативными документами для обязательного исполнения по Российской Федерации не являются.

В связи с вступлением в силу Федерального закона № 323-Ф3, государственная функция выдачи разрешений на применение новых медицинских технологий, исполняемая Росздравнадзором на основании приказа Минздравсоцразвития России от 20.07.2007 г. № 488, утратила законодательную базу.

Таким образом, с 01 января 2012 года разработка, применение в практике здравоохранения новых медицинских технологий (впервые предлагаемые к использованию на территории Российской Федерации или усовершенствованные совокупности методов (приемов, способов) лечения, диагностики, профилактики), а также контроль за их использованием в Российской Федерации законодательно не регулируются.

Кроме того, п. 4 статьи 78 Федерального закона от 21 ноября 11.2011 № 323-Ф3 [5] всем медицинским организациям, независимо от формы собственности, предоставляется право осуществлять научную и (или) научно-исследовательскую деятельность, в том числе проводить фундаментальные и прикладные научные исследования.

Если говорить о здравоохранении в целом, то можно утверждать, что данная правовая норма при отсутствии законодательного регулирования разработки и применения новых методов лечения может привести к массовому бесконтрольному использованию в практике здравоохранения новых, экспериментальных методов лечения с недоказанной эффективностью и безопасностью, что создаст потенциальную угрозу жизни и здоровью гражданам Российской Федерации.

Таким образом, новый федеральный закон «Об основах охраны здоровья граждан в Российской Федерации», нарушает права граждан Российской Федерации на охрану здоровья (ст. 41 Конституции Российской Федерации) [7], не ограничивая применение при оказании медицинской помощи небезопасных и не эффективных методов лечения.

Возникает необходимость внесения дополнений к Федеральному закону от 21.11.2011 г. N 323-Ф3 и обязательной регистрации медицинских 
технологий, используемых при производстве судебно-медицинских экспертиз.

В настоящее время разработка и утверждение медицинских технологий производства судебномедицинских экспертиз вещественных доказательств могут оказаться основным направлением повышения качества экспертной деятельности. Внедрение в практическую работу новейших достижений науки и техническое оснащение лабораторий современным высокотехнологичным оборудованием позволит поднять судебно-медицинскую экспертизу на качественно новый уровень. Широкое применение лабораторных методов исследований расширит возможности для получения объективных данных и повысит доказательность судебно-медицинских экспертиз.

Следует отметить, что стандартизации должны подвергаться только методы, требующие точного исполнения всех пошаговых функций, в которых отклонения в технологии производства даже одного из этапов исследования может привести к неправильному результату либо к неверной интерпретации полученного результата. Анализ же результатов лабораторных исследований не может быть стандартизирован, так как каждое судебно-медицинское заключение, часть которого базируется на заключении эксперта лабораторной службы, носит индивидуальный, а порой и уникальный характер.

Для дальнейшего развития лабораторной службы Бюро СМЭ необходима адаптация нормативной и методической базы к новым методам исследования и к новым видам экспертиз с приме- нением высокотехнологичного оборудования; разработка новых критериев, позволяющих регулировать производственную нагрузку и контролировать качество исследований, а также организация учебных баз для соответствующей подготовки специалистов.

\section{Литература}

1. Медицинские технологии, используемые при производстве судебно-медицинских экспертиз: сборник медицинских технологий / сост. В.А. Клевно. - М.: Компания Планета Земля, 2012. - 400 c.

2. Приказ Минздравсоцразвития России от 12 мая 2010 года № 346н «Об утверждении Порядка организации и производства судебно-медицинских экспертиз в государственных судебно-экспертных учреждениях Российской Федерации». Опубликован в Российской газете 20.08.2010 г.

3. Приказ Минздравсоцразвития России от 31.12.2004 г. № 346 «Об организации выдачи разрешений на применение медицинских технологий». Опубликован в Российской газете 01.03.2005 г.

4. Приказ Минздравсоцразвития России от 20.07.2007 г. № 488 «Об утверждении административного регламента Федеральной службы по надзору в сфере здравоохранения и социального развития по исполнению государственной функции по выдаче разрешений на применение новых медицинских технологий». Зарегистрирован Министерством юстиции Российской Федерации 1 августа 2007 г. (N 9938).

5. Федеральный закон от 21.11.2011 г. N 323-Ф3 «Об основах охраны здоровья граждан в Российской Федерации». Опубликован в Российской газете 23.11.2011г.

6. Конституция Российской Федерации от 25 декабря 1993 года с изменениями от 30 декабря 2008 года. Опубликована в Российской газете 21.01.2009 г.

\section{ПРО НАУКОВО-МЕТОДИЧНЕ ЗАБЕЗПЕЧЕННЯ ЛАБОРАТОРНИХ ДОСЛІДЖЕНЬ ПРИ ВИРОБНИЦТВІ СУДОВО-МЕДИЧНИХ ЕКСПЕРТИЗ}

\section{Н.А. Романько}

Резюме. У статті дана оцінка станом нормативно-правової бази РФ, що регламентує порядок виробництва експертиз трупів, живих осіб, матеріалів справи і біологічних об'єктів. Автор приходить до висновку про необхідність адаптації нормативної та методичної бази до нових методів дослідження і до нових видів експертиз із застосуванням високотехнологічного обладнання, розробки нових критеріїв, що дозволяють регулювати виробниче навантаження і контролювати якість досліджень.

Ключові слова: судово-медичні експертизи, нові технології, нормативно-правові акти.

\section{ON THE SCIENTIFIC AND METHODOLOGICAL SUPPORT OF LABORATORY STUDIES IN THE PRODUCTION OF FORENSIC - MEDICAL EXAMINATION}

\section{N.A. Romanko}

Abstract. This paper assesses the state of the normative-legal base of the Russian Federation, regulating the procedure for making an examination of corpses, survivors, case materials and biological objects. The author comes to a conclusion about a need for an adaptation of the normative and methodological base for new research methods and for new types of examinations with the use of the high-tech equipment; the development of new criteria enabling, to regulate the production load and control the quality of a research.

Key words: forensic-medical examination, new technologies, normative-legal acts.

Bureau of Forensic Medical-Examination (Moscow) 